\title{
Rozwój drukarstwa muzycznego u staroobrzędowców popowców w XIX i na początku XX wieku
}

\begin{abstract}
Daniel Sawicki
Polska

infoechos@wp.pl

Daniel Sawicki, The music printing development with Popovtsy in the 19th century and at the beginning of the 20th century, Elpis, 17 2015: 127-138.

Abstract: The main goal of this article's author is to describe the beginnings of the music printing with the Old Believers acknowledging priests (Popovtsy). The first attempts of printing the orthodox songbooks containing notes have been pioneering. However, there were quite a few editorial as well as printing flaws. The current author, by analyzing priest's professor Dymitr Razumowski contribution into the whole process of songbooks printing, proves that it has been possible to organize edition only thanks to the cooperation between the editor and publisher. Further, there are explained the causes of printed songbooks rejection among the Old Believers not only in Russia but also among those who emigrated. The second part of this work is dedicated to Lasar Kalashnikov's editorial activity carried in Kiev and afterwards in Moscow, especially his great contribution into popularization of different forms of the Old Believers' church singing. Based on the accessible sources, it is described that Kalashnikov's editorial successes have been only possible owing to the fact of the orthodox church authorities' support and political favourable for the Old Believers circumstances.

Streszczenie: Głównym zadaniem, jakie postawił sobie autor przytoczonego artykułu, było nakreślenie początków pojawienia się drukarstwa muzycznego u staroobrzędowców uznających kapłaństwo. Analizując pierwsze przedsięwzięcia w dziedzinie drukowania śpiewników cerkiewnych zawierających nuty, wykazał jego pionierskość. Jednocześnie wskazuje na liczne niedociągnięcia redakcyjne oraz samego druku. Analizując wkład ks. Prof. Dymitra Razumowskiego w cały proces przygotowania do druku śpiewników autor udowadnia, iż realizacja wydania była możliwa tylko dzięki wzajemnej współpracy pomiędzy wydawcą a redaktorem. W dalszej kolejności autor wyjaśnia przyczyny nie przyjęcia nowo wydrukowanych ksiąg przez środowiska staroobrzędowców tak w Rosji, jak i na emigracji. Drugą część pracy autor poświęcił na opisanie działalności wydawniczej prowadzonej w Kijowie a potem w Moskwie przez Łazarza Kałasznikowa, a szczególnie wielkiego wkładu, jaki włożył w popularyzację różnych form staroruskiego śpiewu cerkiewnego. Na podstawie dostępnych źródeł autor wykazał, iż przedsięwzięcia wydawnicze realizowane przez Kałasznikowa zawdzięczają swoje powodzenie poparciu udzielonemu wydawcy przez władze cerkiewne oraz sprzyjającym staroobrzędowcom uwarunkowaniom politycznym.
\end{abstract}

Keywords: liturgical singing of the Orthodox Church, znamenny chant, old Believers

Słowa kluczowe: śpiew liturgiczny kościoła prawosławnego, znamienny śpiew, staroobrzędowcy

Staroruski monodyczny śpiew cerkiewny (znamiennyj raspiew), był i jest jednym z istotniejszych przejawów świadczących o bogactwie kultury duchowej „Starej Rusi”. Szczególne miejsce śpiew ten zajmuje w życiu liturgicznym staroobrzędowców ${ }^{1}$. To właśnie staroobrzędowcy, mimo trwających wiele wieków prześladowań tak ze strony władz carskich, jak i oficjalnej Cerkwi jako jedyni uchronili unikatowe formy staroruskiego śpiewu cerkiewnego wraz z kriukową notacją neumatyczną od zapomnienia. Niemal do końca 2-giej połowy XIX wieku jedynym sposobem rozpowszechniania przez staroobrzędowców kriukowych śpiewników, było ich mozolne przepisywanie. Przy każdym ważniejszym ośrodku życia duchowego staroobrzędowców działały wyspecjalizowane skryptoria, gdzie przepisywano, zdobiono i oprawiano kriukowe księgi liturgiczne. Mimo to coraz częściej odczuwano brak śpiewników drukowanych.

Zabiegi zmierzające do opracowania i wydania drukiem jednolitego zbioru śpiewów liturgicznych, można za-

O znaczeniu terminu „staroobrzędowcy”, zob.: D. Sawicki, Kwestia "razdielnorieczija” i śpiewu wielogłosowego w nauczaniu staroobrzędowców rosyjskich, ELPIS, t. 16, s. 201, przyp. 6. obserwować na Rusi już na początku 2-giej połowy XVII wieku. W tym samym czasie trwały reformy liturgiczne zainicjowane przez patriarchę Nikona, które ostatecznie potwierdził sobór 1666-1667 r. Głównym celem reformy liturgicznej, było upodobnienie ówcześnie obowiązujących na Rusi obrzędów do ich greckich odpowiedników oraz korekta ksiąg liturgicznych ${ }^{2}$. Pod płaszczykiem rzekomych błędów w księgach liturgicznych oraz obrzędach wprowadzano do liturgii nowe trendy estetyczne, które znajdowały swoje odzwierciedlenie $\mathrm{w}$ architekturze, ikonografii oraz śpiewie cerkiewnym ${ }^{3}$. Jeden z punktów reformy, zakładał uporządkowanie starych (monodycznych) śpiewów cerkiewnych, wraz ujednoliceniem zasad czytania kriuków $w^{4}$. Do tego celu powołano specjalną komisję, na czele której

\footnotetext{
И. Сахаров, Исследования о русском церковном песнопении, „Журнал Министерства Народного Просвещения", Вып. LXI-LXI, 1849, s. $277-278$.

3 В. Бычков, Русская средневековая эстетика XI-XVII века, Москва 1995, s. 543-588.

4 D. Sawicki, Pierwsze próby reform śpiewu cerkiewnego na Rusi. Działalność I i II Komisji (1652-1670), ELPIS, Rocznik XV (XVI), Zeszyt 27(40), s. 142-143.
} 
stanął jeden z wybitniejszych znawców śpiewu - Aleksandr Miezieniec $^{5}$. Niewykluczone, iż to właśnie Miezieniec wraz $\mathrm{z}$ komisją pracował nad przygotowaniem do druku pełnego „Cyklu” zreformowanych śpiewów cerkiewnych ${ }^{6}$. W tym celu na moskiewskim Pieczatnym Dworze odlano specjalistyczne czcionki drukarskie zawierające kriuki ${ }^{7}$. Wydrukowanie ksiąg zawierających jakiekolwiek nuty, a tym bardziej kriuki, a do tego opatrzone tzw. kinowarnymi pomietami ${ }^{8}$, wymagało zastosowania techniki podwójnego druku, co przy możliwościach ówczesnych pras

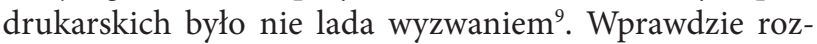
ważano zastąpienie kinowarnych pomiet innymi znakami w kolorze czarnym, co mogło uprościć druk. Ostatecznie, ze względu na wysokie koszty druku, władze Pieczanego Dworu zdecydowały zawiesić prace nad wydaniem ksiąg liturgicznych zawierających kriuki ${ }^{10}$. O ostatecznym odstąpieniu od pomysłu drukowania śpiewników zadecydował jeszcze jeden ważny czynnik, a mianowicie wzrost zainteresowania śpiewami wielogłosowymi (ros. partiesnoje pienije ), które stopniowo wypierały z użytku liturgicznego rodzimą monodię ${ }^{11}$.

Reforma śpiewów cerkiewnych, zainicjowana w $1652 \mathrm{r}$. pracami I Komisji obok ujednolicenia repertuaru, zakładała także przywrócenie „starej mowy prawdziwej” tekstom liturgicznym zawartym w kriukowych śpiewnikach ${ }^{12}$. Cel szczytny, lecz możliwości przeprowadzenia reformy na ogólnopaństwową skalę znacznie ograniczone. Jej osta-

„Соблагоизволися благочестивъйшему и въликому государю нашему, царю и великому князю Алексию Михайловичу, всея Великия и Малыя и Бълыя Россіи самодержцу: во преходящее время льта 1655 о церковном пъніи знаменном пьніи предълъ учинити, еже бы всякое пъніе было воистиннорьчном пьніи, вездъ во градъхъ и честныхъ обителехъ и сельхъ устроено равночинно, и доброгласно. И в тое время на тое божественное и святыя божія церкве дьло, его Царьскимъ повельніемъ во царствующемъ велицъмъ градъ Москве дидаскаловъ собрано къ тому знаменному устроенію разныхъ чиновъ отъ святыя божія церкве чиноначальниковъ и всякаго церковнаго чина избранныхъ людей 14 человъковъ. И от того времене учиниша от иностранныхъ окрестныхъ царствъ рати и брани, въ нихъ же многия царственныя и земския бъша великия дъла. Еще въ тъже времена гръхъ ради нашихъ приидъ и моровое повътріе”. Суt. za: А. Мезенец, Извещение о согласнейших пометах, изд. Ст. Смоленский, Казань 1888, s. 1.

6 Z. Lissa, Historia Muzyki Rosyjskiej, Warszawa 1955, s. 74-75.

XIX-wiecznemu badaczowi tematu - P. Bessonowowi, udało się dotrzeć do wykazu mienia drukarskiego, jakie w 1681 roku posiadał moskiewski Pieczatnyj Dwor. Otóż widnieje tam wzmianka o posiadaniu całej gamy kriukowych czcionek drukarskich odlanych przez niejakiego Iwana Andriejewa. -Zob.: П. Бессонов, Судьба нотньх певческих книг, „Православное Обозрение", 1864, T. XIV, s. 28

8 Kinowarnyja pomiety - znaki pomocnicze staroruskiej notacji neumatycznej wprowadzone w celu precyzyjnego określenia wysokości dźwięku. Por. В. Металлов, Очерк истории Православнаго церковнаго Пения, Москва 1915, s. 50.

9 В. Мартынов, История богослужебного пения, Москва 1994, s. 117.

10 Е. Поспелов, Крюковое осмогласие, „Церковное Пение”, 1909, nr 1 , s. $10-18$

11 Ю. Келдыш, История русской музыки, Т, I, Мосва 1983, s. 169 ; D. Sawicki, Kwestia „razdielnorieczija” i śpiewu wielogłosowego..., dz. cyt., s. 206-208.

12 Tenże, Staroje istinnorieczije i razdielnorieczije jako dwie główne epoki w dziejach śpiewu liturgicznego na Rusi od XI w. do XVII w., [w:] „Z badań nad językiem i kulturą Słowian”, red. P. Sotirov i P. Złotkowski, Lublin 2007, s. $169-178$ teczne niepowodzenie przypieczętował rozłam (cs. raskoł), jaki powstał w wyniku nieumiejętnego przeprowadzenia przez patriarchę Nikona reform liturgicznych. Niechęć zwolenników „starej wiary” wobec wszelkich nowinek wprowadzonych do nabożeństw skutecznie uniemożliwił przekład staroruskich śpiewów cerkiewnych na prostszy do opanowania zapis nutowy. Upór staroobrzędowców zmierzający do zachowania rodzimych tradycji śpiewu nie poszedł na marne, a przyczynił się dalszego podtrzymywania różnorodności jego form przy jednoczesnym zachowaniu podstawowych elementów struktury melodycznej staroruskiego śpiewu cerkiewnego, tj. formuł melodycznych (popiewek, lic i fit $)^{13}$. Zepchnięci na margines społeczny oraz poddawani licznym prześladowaniom zarówno ze strony władz państwowych, jak i cerkiewnych, staroobrzędowcy, nie mieli możliwości zakładania typografii. Co więcej, skomplikowania samego druku sprawił, iż wydawanie śpiewników było w warunkach konspiracji przedsięwzięciem niemożliwym do zrealizowania.

Wprowadzenie w życie reform liturgicznych patriarchy Nikona, potwierdzone na soborach 1666-1667 r. zbiegło się w czasie z pojawieniem się wśród znawców śpiewu tendencji zmierzających do jego unifikacji, poprzez odgórne narzucenie chórom cerkiewnym określonego repertuaru. Osiągnięcie zamierzonego celu przy pomocy ksiąg przepisywanych ręcznie było raczej niemożliwe. Co więcej, sami kopiści niejednokrotnie wnosili do śpiewników własne interpretacje tych, czy innych melodii. W jego realizacji niewątpliwie pomógłby druk śpiewników, co jak już wcześniej wspomniano było przedsięwzięciem nie do zrealizowania. Wprawdzie rozważano wydrukowanie śpiewników z zastosowaniem kijowskiej notacji kwadratowej (kijewskoje znamia), co byłoby znacznie tańsze i prostsze do zrealizowania. Wzorowana na liniowej notacji gregoriańskiej notacja kijowska pojawiła się w Państwie Moskiewskim pod koniec 1-szej połowy XVII wieku, za sprawą śpiewaków kijowskich, którym patronował car Aleksy Michajłowicz ${ }^{14}$. Przybywający do Moskwy z terytoriów należących do Rzeczypospolitej śpiewacy, przywozili ze sobą nutowe księgi liturgiczne, w większości monodyczne Irmologiony ${ }^{15}$. Jako ciekawostkę należy podać fakt, iż niemal do końca XVI wieku, czyli do zawarcia Unii Brzeskiej (1596 r.), na teryto-

\footnotetext{
13 Lica i fity - formuły melodyczne melizmatycznego typu funkcjonujące w większości wariantów staroruskiego śpiewu cerkiewnego. Zob.: М. Бражников, Лица и фиты знаменного распева, Ленинград 1984, por. W. Wołosiuk, Wschodniosłowiańskie pieśni religijne. Ich geneza, struktura oraz zarys rozwoju, Warszawa 2013, s. 100, przyp. 268.

14 Д. Разумовский, Церковное пение в России, Москва 1867-69, s. $80-81$.

15 Irmologion - cs. Księga liturgiczna zawierająca w sobie irmosy tj. pieśni z oktoicha śpiewane m.in. podczas jutrzni. Całość materiału podzielona jest na 8 tonów cs. głasow. Księga zajmuje czołowe miejsce w liturgii staroobrzędowców. Е. Григорьев, Пособие по изучению иерковного пения и чтения, Рига 2001, s. 311. Z biegiem czasu do Irmologionu zaczęto dodawać inne śpiewy nabożeństw Całonocnego Czuwania oraz Świętej Liturgii, czego przykładem jest tzw. Irmologion supraski. Zob.: W. Wołosiuk, Irmologion Supraski, „Rocznik Teologiczny”, rok. XLVI, Warszawa 2004/2 ; Ю. Ясіновський, Візантійська гимнограбія $і$ церковна монодія в украӥнськой рецепиії ранньо-модерного часу, Львів 2011.
} 
riach Rzeczypospolitej w prawosławnych świątyniach dominował śpiew monodyczny ${ }^{16}$. Mimo istotnych różnic jego melodyka nawiązuje do pierwotnych form staroruskiego śpiewu neumatycznego (znamiennyj raspiew ${ }^{17}$ ). $\mathrm{Z}$ jakich względów, ostatecznie odstąpiono od pomysłu wykorzystania kijowskich znamion w druku śpiewników? Tego do końca nie wiadomo. Być może na przeszkodzie stanęła konserwatywna frakcja wśród śpiewaków cerkiewnych, która notację kijowską uważała za przejaw wpływów zachodnich $^{18}$.

Do pomysłu drukowania śpiewników powrócono w Rosji na początku XVIII wieku. Z całą pewnością można powiedzieć, iż był to efekt działalności wydawniczej unickiego zakonu bazylianów. Otóż w 1697 roku spod pras bazyliańskiej oficyny wydawniczej działającej przy monasterze w Supraślu wychodzi druk pt. Posliedowanije postrigu (Profesja zakonna), gdzie zamieszczono troparion Obiatija Otcza opatrzony zapisem nutowym ${ }^{19}$. Na tym bazylianie nie poprzestali, bo już w 1700 roku $^{20}$ rozpoczęli druk śpiewników (Irmologionów) w swoich oficynach wydawniczych przy klasztorach we Lwowie i Poczajowie ${ }^{21}$. Niezależnie od bazylianów, prace nad wydawaniem śpiewników rozpoczęla oficyna wydawnicza Bractwa Stauropigialnego we Lwowie ${ }^{22}$. W nagrodę za przystąpienie do unii, Bractwo otrzymało w 1708 roku prawo do drukowania ksiąg liturgicznych na użytek cerkiewny, które wcześniej przysługiwało lwowskim bazylianom ${ }^{23}$. Staraniem bractwa stauro-

\footnotetext{
16 Tenże, Znaczenie eparchii Przemyskiej w rozwoju ukraińskiej muzyki cerkiewnej, [w:] Polaska-Ukraina 1000 lat sąsiedztwa, red. S. Stępień Przemyśl 1994, T. II, s. 406-408.

Termin raspiew (in. rospiew) w staroruskim śpiewie cerkiewnym oznacza system melodii określonego typu (wzorzec melodyczny) oparty na zasadzie ośmiu skal modalnych (cs. Osmogłasija), władający określonym systemem formuł melodycznych (cs. popiewek) oraz melizmatycznych (cs. lic i fit). Odpowiedni dobór popiewek, jak również rozpiętość linii melodycznych określa typ raspiewa. Każdy raspiew posiada również skreślone normy estetyczne oraz metody łączące element muzyczny z tekstem liturgicznym. Określeniem pochodnym jest rozśpiewywać (cs. raspiewywat'), który oznacza nic innego, jak opatrywanie tekstu liturgicznego znakami notacji neumatycznej. Г. Печенкин, Возвашник: Возвахи знаменного роспева: Обиходное осмогласие: Опыт исследования, истолкования, практики знаменного пения и методика обучения, Москва 2010. s. 116 ; И. Гарднер, Богослужебное пение Русской Православной Церкви, Т. І., Москва 2004, Т. I, s. 205, por. М. Бражников, Русская пев-
} ческая палеограбия, Санкт-Петербург 2002, s. 185.

18 Do tejże frakcji śpiewaków cerkiewnych należał także reformator Aleksandr Miezieniec. Zob.: A. Мезенец, Извещение о согласнейших..., s. 1-2, por. Ст. Смоленский, Примечания къ Азбуке Мезенияа, Казань 1888 , s. 44

19 Publikacja doczekała się dwóch przedruków w 1750 i 1793 roku.

20 Pierwsze lwowskie wydanie Irmologionu, obok pieśni z Oktoechosu, zawierało także śśpiewy niezmienne $\mathrm{z}$ nabożeństw: Całonocnego Czuwania, Świętej Liturgii oraz Triodionów. Por. M. Florczak, Śpiewy liturgiczne Rosyjskiej Cerkwi prawosławnej, zarys historyczno-analityczny, Warszawa 2013, s. 77.

${ }_{21}$ M. Przywecka-Samecka, Dzieje drukarstwa muzycznego $w$ Polsce do końca XVIII wieku, Wrocław 1993, s. 205-213; M. Pidłypczak-Majerowicz, Bazylianie w Koronie i na Litwie. Szkoły i ksiażki w działalności zakonu, Warszawa - Wrocław 1986, s. 72, por. И. Гарднер, Богослужебное пение..., T. II, dz. cyt., s. 111.

22 Ю. Ясіновський, Візантійська гимнографія..., dz. суt., s. 348.

23 Jedynym przedsięwzięciem wydawniczym, jaki udało się zrealizować bazylianom lwowskim po 1708 roku, był druk Kalendarza na roku 1732. Por. M. Pidłypczak-Majerowicz, Bazylianie w Koronie..., dz. cyt., s. 71-72. pigialnego w 1709 roku ukazało się nowe - poprawione wydanie Irmologion $u^{24}$, które tylko $\mathrm{w}$ niewielkim stopniu różniło się od bazyliańskiego z 1700 roku. Wkrótce, w latach 1766,1775 i 1794, pojawiły się nowe nakłady Irmologionu - poprawione i uzupełnione. Z czasem, Irmologion lwowski stał się w XVIII wieku podstawowym śpiewnikiem liturgicznym w klasztorach Ukrainy, tak prawosławnych, jak i unickich ${ }^{25}$. Wydawane przez Bractwo oraz bazylianów Irmologiony za sprawą śpiewaków ukraińskich dotarły na Białoruś i do Mołdawii ${ }^{26}$. Regularnie przemycano je także do Rosji, jednakże tamtejsi śpiewacy odnosili się do nich $\mathrm{z}$ dużym dystansem ${ }^{27}$.

Osiągnięcia bazylianów i Bractwa Stauropigialnego we Lwowie w dziedzinie drukowania śpiewników cerkiewnych sprawiły, iż także w Rosji poważnie zajęto się pracami nad realizacją druku ujednoliconych śpiewników cerkiewnych, $i$ to na o wiele szerszą skalę ${ }^{28}$. Rozpoczęte na początku XVIII wieku prace, za sprawą wielu czynników trwały o wiele dłużej, niż pierwotnie zakładano. Trudu wydania „cyklu” śpiewników podjął się redaktor, a następnie sekretarz Drukarni Synodalnej - Stefan Byszkowski. W latach 1766-1767 Byszkowskiemu udało się opracować, a następnie przedstawić do zatwierdzenia przez komisję synodalną kompletny projekt druku śpiewników wraz z kosztorysem oraz próbkami własnoręcznie odlanych znaków nutowych wzorowanych na kijowskiej notacji kwadratowej. O dziwo znaki te łudząco przypominały czcionki wykorzystane w wydaniach lwowskich, co nie uszło uwadze cenzorów. Z uwagi na wysokie koszty druku, Świątobliwy Synod zdecydował uwzględnić tylko niektóre elementy projektu Byszkowskiego, zalecono także odlanie nowych czcionek, które odróżniałyby wydania rosyjskie, od ich unickich odpowiedników wydawanych we Lwowie i Poczajowie ${ }^{29}$. Równie ważną rolę $\mathrm{w}$ procesie przygotowawczym wydania odegrał ukraiński śpiewak „generał-bas” petersburskiej nadwornej kapeli - Hawriiło Hołownia (1706-1786). Niezbędne wykształcenie muzyczne zdobył w Głuchowie na Ukrainie. Będąc już w Petersburgu, Hołownia zredagował dwa Irmologiony, które zostały wykorzystane przy realizacji wydania śpiewników synodalnych. Z czasem pojawił się pomysł wydania tychże Irmologionów w formie jednej publikacji, lecz wskutek odmowy finansowania wydania $\mathrm{z}$ budżetu Świątobliwego Synodu nie został on zrealizowany ${ }^{30}$. Na taką a nie

\footnotetext{
We wstępie do poprawionego wydania Irmologionu czytamy: „Ірмологіон сиръчь пъснословъ. Твореніе преподобнаго отца нашего Іоанна Дамаскина и прочихъ богодухновенныхъ Отец. Изданъ: Тщаніемъ же братства Ставропигіонъ Львовскаго храма Успенія Пресвятыя Богоматере. Року 1709. Маія 15-го". Суt. za: Ірмологіон нотныцй, Львов 1709 (Druk. Bractwa Stauropigialnego), BN. Cyr. 455.

25 W. Wołosiuk, Wschodniosłowiańscy kompozytorzy muzyki cerkiewnej od XVII do 1. połowy XX wieku i obecność ich utworów w nabożeństwach PAKP, Warszawa 2005, s. 102.

26 Ю. Ясіновський, Візантійська гимнографія...,dz. суt., s. 357.

27 И. Вознесенский, Церковное пение православной юго-западной Руси по нотолинейныь ирмологам XVII и XVIII веков, Вып. 1, Москва 1898, s. 5-7.

28 Б. Кудрик, Огляд історії української церковної музики, Львів 1995, s. 22.

29 В. Металлов, Очерк истории..., dz. cyt., s. 62.

30 И. Гарднер, Богослужебное пение...,Т. II, dz. cyt., s. 119.
} 
inną decyzję władz cerkiewnych miał niewątpliwie wpływ fakt, iż Hołownia zażądał wysokiego wynagrodzenia już za samo udostępnienie rękopisu ${ }^{31}$. Ułożył także elementarz do nauki śpiewu nutowego tak jednogłosowego, jak partesnego, który także zamierzał wydać drukiem, lecz i tym razem spotkał się z odmową ${ }^{32}$.

W latach 1770-1772 wydano pełen cykl monodycznych śpiewów cerkiewnych, które do 1917 roku doczekały się kilkudziesięciu przedruków ${ }^{33}$. Wszystkie śpiewniki drukowano z zastosowaniem wspomnianej już kijowskiej notacji kwadratowej. O wydrukowaniu ksiąg zawierających kriuki nie było mowy, bowiem już pod koniec 1-szej połowy XVIII wieku wyszły z powszechnego użytku. Staroruskie notacje muzyczne uchronili przed zapomnieniem staroobrzędowcy, dla których były one ważnym symbolem ojczystej kultury duchowej. Mimo złagodzonej polityki niektórych władców wobec staroobrzędowców, długo nie zezwalano im na zakładanie własnych typografii. Księgi liturgiczne na potrzeby wspólnot staroobrzędowców drukowały wprawdzie oficyny wydawnicze bazylianów w Supraślu ${ }^{34}$ i Poczajowie ${ }^{35}$, lecz nie posiadały one nut. Nikt wśród staroobrzędowców nawet nie pomyślał i drukowaniu ksiąg zawierających kriuki. Obok kwestii czysto technicznych istniały ku temu poważne przeszkody natury mentalnej. Dla staroobrzędowców druk śpiewników oznaczał niejako odstąpienie, od wielowiekowych tradycji mozolnego przepisywania śpiewników, co naruszało swoiste sacrum. Swój negatywny stosunek wobec takich pomysłów, starowiercy tłumaczyli chęcią uchronienia unikalnych staroruskich śpiewów przed skażeniem. Jeśli już korzystali z ksiąg drukowanych, to tylko z wydanych do 1652 roku, czyli do reform patriarchy Nikona ${ }^{36}$. Sytuacja naszym zdaniem mogłaby ulec zmianie, gdyby pozwolono staroobrzędowcom drukować księgi liturgiczne na własny użytek.

Pomysł wydania kriukowych ksiąg liturgicznych na nowo ożył w 1850 roku za sprawą pionierskich jak na owe czasy badań nad historią i teorią staroruskiego śpiewu cerkiewnego. W tym miejscu należałoby przywołać postać ks. Dymitra Razumowskiego, znamienitego znawcy sta-

\footnotetext{
31 Tamże, s. 159.

32 Ю. Ясіновський, Візантійська гимнографія...,dz. суt., s. 300.

П. Бессонов, Судьба нотных певческих книг, „Православное Обозрение», 1864, Т. XIV ; И. Вознесенский, О церковном пении Православной Греко-Российской Церкви: Большой и мальй знаменный роспев, Рига, 1890, s. 99, por. Б. Кутузов, Русское знаменное пение, Москва 2008, s. 232

34 W świetle ustaleń Z. Jaroszewicz-Pieresławcew, oficyna supraska wydrukowała na potrzeby staroobrzędowców łącznie 45 pozycji, co klasyfikuje ją na pierwszym miejscu pośród drukarń w Rzeczypospolitej.

Zob.: Z. Jaroszewicz-Pieresławcew, Druki cyrylickie z oficyn Wielkiego Księstwa Litewskiego w XVI-XVIII wieku, Olsztyn 2003, s. 128, ; Ю. Лабынцев, Памятники древнерусской книжности и литературь в старообрядческих изданиях Супрасльской типограбии (XVIIIв.) „Труды Отдела древнерусской литературы” 1981, Т. 36, s. 209-215.

35 Druki staroobrzędowe wychodziły spod pras oficyny poczajowskiej nieregularnie, co utrudnia kompleksowe ich opracowanie. Co więcej, inne często prywatne drukarnie starowierskie zafałszowywały adres wydawniczy swoich druków podając Poczajów jako miejsce ich druku. Por. M. Pidłypczak-Majerowicz, Bazylianie w Koronie..., dz. cyt., s. 76.

36 Ст. Смоленский, Примечания къ Азбуке..., dz. cyt., s. 45-46.
}

roruskiego śpiewu cerkiewnego ${ }^{37}$. Urodzony 26 października 1818 r. (według innych danych w 1823 r.) w Kijowie w rodzinie duchownego, studiował do Kijowskiej Akademii Duchownej, którą ukończył w 1843 roku. Droga kariery duchownej okazała się nie jedyną w życiu ks. Dymitra, bardziej od pracy duszpasterskiej interesowała go nauka, a ściślej mówiąc śpiew cerkiewny. Karierę naukową ks. Dymitr Razumowski rozpoczyna w charakterze wykładowcy fizyki, matematyki i języka hebrajskiego na w seminarium duchownym, działającym przy monasterze Spaso-Betańskim (Siergiejew-Posad) ${ }^{38}$. Przyjąwszy w 1850 r. święcenia kapłańskie, ks. D. Razumowski pełnił posługę duszpasterską w kilku parafiach Moskwy, gdzie zyskał opinię dobrego kapłana. Mimo wielu obowiązków duszpasterskich, żywo interesował się śpiewem cerkiewnym, szczególnie jego historią teorią. Opanowawszy wszystkie staroruskie notacje neumatyczne dokonał licznych analiz śpiewów monodycznych, czym wypełnił braki w ówczesnym stanie wiedzy. To właśnie ks. Razumowski jako pierwszy zdefiniował pojęcie znamiennogo raspiewa, które rozumiał jako śpiew zapisywany za pomocą neum (cs. znamion) w przeciwieństwie do śpiewów (również monodycznych), zapisywanych za pomocą zachodnich zapisów nutowych (in. notnoje pienije) ${ }^{39}$. Takie stanowcze rozgraniczenie obydwu pojęć spodobało się staroobrzędowcom, z którymi ks. Razumowski utrzymywał szerokie kontakty.

Doceniając dotychczasowe dokonania badawcze ks. D. Razumowskiego, władze cerkiewne powołały go w $1858 \mathrm{r}$. w skład komisji, której zadania sprowadzały się do sprawdzenia używanych w liturgii śpiewników i ich ewentualną korektę. Prowadząc zakrojone na szeroką skalę badania nad najstarszymi zabytkami staroruskiej sztuki muzycznej, ks. D. Razumowski zgromadził bogatą kolekcję zabytków staroruskiej sztuki muzycznej ${ }^{40}$. Z jego inicjatywy powstała w 1866 r. przy Konserwatorium Muzycznym w Moskwie Katedra historii śpiewu cerkiewnego, której został pierwszym kierownikiem ${ }^{41}$. Efektem jego wieloletnich poszukiwań badawczych, było dzieło pt. Śpiew cerkiewny w Rosji, które niewątpliwie należy uznać za pierwsze kompendium wiedzy $\mathrm{w}$ zakresie historii i teorii śpiewu cerkiewnego. Autor porusza tam szereg zagadnień natury historycznej i teoretycznej, które podpiera licznymi przykładami, zaczerpniętymi z kriukowych ksiąg liturgicznych ${ }^{42}$. Mimo wielu zalet, publikacja autorstwa ks. D. Razumowskiego posiadała jedną zasadniczą wadę, a mianowicie brak odpowiedniego aparatu naukowego. Co więcej, w niektórych miejscach pracy ks. Razumowskiego czytelnik może mieć trudności z oddzieleniem rzeczywistości historycznej wła-

\footnotetext{
37 И. Гарднер, Богослужебное пение..., Т. II, dz. суt., s, 342.

38 Н. Финдейзен, протоіерей Д. В. Разумовский (Очерк его деятельности), „Русская Музыкальная Газета”, 1894, nr 9, s. 174-175.

39 Tamże, s. 176

40 Większość rękopisów muzycznych zgromadzonych przez ks. Razumowskiego znajduje w zbiorach Rosyjskiej Biblioteki Narodowej w Moskwie, pod sygn. НИОР РГБ, ф. 379.

41 А. Преображенский, Разумовский, Димитрий Васльевичъ, „Русская Музыкальная Газета", 1897, nr 4, s. 622-623.

42 Н. Тальберг, История русской ц,еркви, Москва 2004, s. 872.
} 
snych tez i spekulacji autora ${ }^{43}$. Pracę ks. Razumowskiego wieńczy wykaz znaków notacji kriukowej, opracowany $\mathrm{w}$ formie dodatku. $\mathrm{Z}$ cała pewnością nie była to jeszcze Azbuka w pełnym znaczeniu tego słowa, bowiem nie zawierała żadnych komentarzy odnoszących się do sposobu wykonywania poszczególnych znaków ${ }^{44}$. Mimo wielu niedoskonałości, był to pierwszy w Rosji druk zawierający kriuki. Nic więc dziwnego, że niemal od razu wzbudził zainteresowanie staroobrzędowców.

Właściwe prace nad wydaniem jednolitego „Cyklu” staroobrzędowych śpiewów cerkiewnych rozpoczęły się dopiero w 1883 roku i trwały dwa lata. Inicjatorem tego jak na owe czasy karkołomnego przedsięwzięcia, był znamienity kupiec moskiewski - staroobrzędowiec Arseniusz Iwanowicz Morozow. W tym miejscu należy zaznaczyć, iż nie szczędząc środków ród Morozowych otaczał swoim mecenatem różnorakie dziedziny staroruskiej kultury i sztuki. $\mathrm{Z}$ inicjatywy A. Morozowa powstał znamienity chór, od nazwiska patronów zwany „Morozowskim. Nad prawidłową realizacją wydania czuwały władze Stowarzyszenia Miłośników Dawnego Piśmiennictwa, jak na owe czasy było wydarzeniem bezprecedensowym. Zadziwiający jest sam fakt, iż wydanie śpiewników zrealizowano na dwadzieścia lat przed wejściem w życie ukazu tolerancyjnego cara Mikołaja II (1905 r. $)^{45}$.

Nad prawidłową realizacją wydania czuwali dwaj znamienici uczeni: historyk - Gienadij Fiodorowicz Karpow (z ramienia Stowarzyszenia) oraz wspomniany już ks. Dymitr Razumowski. To właśnie dzięki ich aktywnej współpracy, wydanie pełnego „Cyklu” kriukowych ksiąg liturgicznych w ogóle stało się możliwym do zrealizowania $^{46}$. Materiał źródłowy wykorzystany do realizacji wydania, wedle najnowszych ustaleń należał do dyrygenta chóru „Morozowskiego” - I. Fortowa, któremu A. Morozow jako pierwszemu zlecił przygotowanie wydania. Nie mogąc sprostać powierzonemu zadaniu, Fortow zwrócił się do wpływowego członka Stowarzyszenia Miłośników Dawnego Piśmiennictwa, G. Karpowa z prośbą o pomoc. $\mathrm{W}$ przedmowie do pierwszego tomu „morozowskiego Cyklu” kriukowych ksiąg liturgicznych Karpow pisze: „Na początku tamtego (1883) roku szlachetnie urodzony obywatel Arseniusz Iwanowicz Morozow zwrócił się do mnie $\mathrm{z}$ prośbą o pomoc w wydaniu $<$ Cyklu starych śpiewów cerkiewnych znamiennago raspiewa $>$ - zawierającego kriukowe nuty. Przedstawił mi do wglądu przepięknie wykonany przez Iwana Awierianowicza Fortowa rękopis tychże nut.

\footnotetext{
43 И. Гарднер, Богослужебное пение..., Т. II, dz. cyt., s. 37.

44 Tamże, s. 471.

45 Ukaz tolerancyjny z 1905 roku cara Mikołaja II umożliwił staroobrzędowcom wszystkich konfesji swobodne wyznawanie wiary. Wówczas odpieczętowano ołtarze głównych staroobrzędowych cerkwi na cmentarzu Rogoskim w Moskwie, co symbolizowało koniec epoki prześladowań. Staroobrzędowcom pozwolono na swobodne wydawanie literatury religijnej, a wszystkie ważniejsze zgromadzenia i sobory mogły odbywać się jawnie. Fakt zrównania praw staroobrzędowców z innymi wyznaniami w Rosji, w tym również Cerkwią prawosławną, był wydarzeniem bezprecedensowym. - Zob.: Ф. Мельников, Краткая история древлеправославной (старообрядческой) Церкви, Барнаул, 1999, s. 398-399, 408-409.

46 И. Дынникова, Морозовский хор в контексте старообрядческой культуры начала ХХ века, Москва 2009, s. 231.
}

Otóż kriukowe nuty dawno już interesowały uczonych, dlatego też uznałem za swój obowiązek uczynić wszystko, co w mojej mocy, aby skierowaną do mnie prośbę wypełnić w sposób należyty" ${ }^{47}$. Nie będąc specjalistą w dziedzinie śpiewu, Karpow wystąpił do władz Stowarzyszenia z propozycją, włączenia w prace ks. Dymitra Razumowskiego, na co otrzymał zgodę ${ }^{48}$. Do jego zadań należało czuwanie nad muzyczną stroną realizacji wydania, poprzez dobór odpowiedniego materiału źródłowego oraz jego korektę ${ }^{49}$.

Pierwotnie, zamierzano wykorzystać te same czcionki i matryce, którymi w 1869 roku wydrukowano trzecią część dzieła ks. D. Razumowskiego pt. Śpiew cerkiewny w Rosji. Ostatecznie, bądź co bądź w obawie przed niską jakością druku, zastosowano metodę fototypicznego facsimile ${ }^{50}$. Przy wyborze drukarni nie decydowała cena, lecz jakość, stąd wybór padł na petersburską drukarnię D. Bałaszewa. Morozow przewidywał wydanie cyklu w nakładzie po 1200 egzemplarzy każdego tomu ${ }^{51}$. Jednak już w trakcie przygotowania do druku pierwszego tomu „Cyklu”, pomiędzy A. Morozowym, a władzami Stowarzyszeniem Miłośników Dawnego Piśmiennictwa rozgorzał spór o prawo do sprzedaży ksiąg. Nie mając gwarancji zbytu wydawcy zadecydowali zmniejszyć nakład o połowę.

Ostatecznie „Cykl” „morozowskich” śpiewników ukazał się drukiem sześciu częściach, na które składały się: I: Oktoich (Oktaj) ${ }^{52}$ II: Śpiewy użytkowe Całonocnego Czuwania (Obichod Wsienoszcznogo Bdienija) III: Śpiewy Świętych Liturgii (Obiednica) IV: Śpiewy świąt z liczby dwunastu (Prazdniki) V: Śpiewy pozostałych świąt i świętych (Trezwony) VI: Irmologion (Irmołoj) $)^{53}$. Realizację druku podzielono na kilka etapów, co w znaczącym stopniu obniżało jego koszt, jednocześnie ułatwiało dystrybucję śpiewników. Każdą z sześciu części wydrukowano w formacie in folio, dzięki czemu doskonale nadawały się do użytku liturgicznego ${ }^{54}$. Pierwszy tom „Cyklu” poprzedza obszerne wprowadzenie do dziejów staroruskiej notacji neumatycznej autorstwa ks. Dymitra Razumowskiego, na które składały się części historyczna oraz zawierająca objaśnienie znaczenia podstawowych znaków notacji neumatycznej część teoretyczna. Co ciekawe, objaśnienia dokonano nie jak dotychczas za pomocą kwadratowej nuty, lecz zapisu nutowego bliskiego współczesnemu ${ }^{55}$.

\footnotetext{
Круг иерковного древнего знаменного пения, Санкт-Петербург 1884, Ч. 1, s. I. (Tłum. autor).

48 И. Дынникова, Морозовский хор..., dz. суt., s. 235.

49 Круг иерковного..., Ч. 1, s. III.

50 Tamże, s. II.

51 Tamże, s. I, por. И. Дынникова, Морозовский хор..., dz. суt., s. 239.

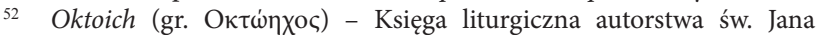
z Damaszku zawierająca porządek nabożeństw na niedziele i dni cyklu tygodniowego rozdzielonego w ciągu roku wg ośmiu tonów cs. głasow. Z biegiem czasu w skład Oktoicha weszły stichery ewangeliczne, których autorstwo przypisuje się Leonowi Mądremu - synowi Aleksandra Macedończyka. Z czasem utrwalił się współcześnie znany podział Oktoicha na Mały i Wielki. Zob.: apx. Модест, O иерковном октоихе, Вильна 1865, s. 59-77, por. Д. Разумовский, Богослужебное пение Православной Греко-Российской Церкви. Москва 1886, s. 32.

53 Ф. Мельников, Краткая история..., dz. суt., s. 460.

54 И. Гарднер, Богослужебное пение..., Т. II, dz. cyt., s. 345.

55 Д. Разумовский, О знаменном роспеве, [w:] Круг иерковного..., Ч. 1, s. X-XXIII, por. tenże, Церковное пение..., dz cyt., s. 271-365.
} 


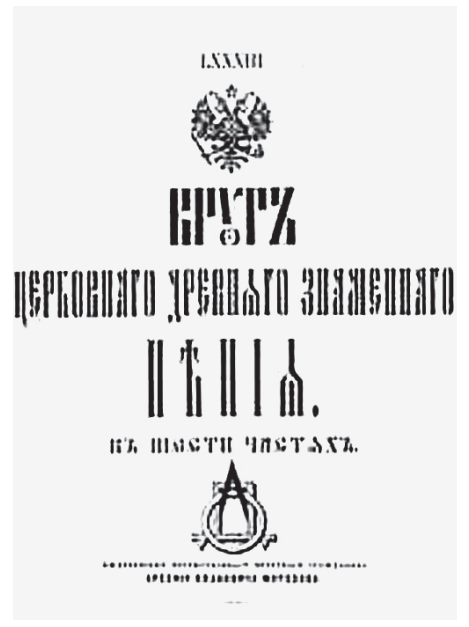

Strona tytułowa „Cyklu” A. Morozowa

Świeżo wydrukowane śpiewniki, A. Morozow polecił rozesłać po wszystkich ważniejszych szkołach teologicznych Rosji, co w naszej ocenie było nie do końca trafnym posunięciem, narażało wydawcę na oskarżenia o szerzenie idei Raskotu. Kierując się chęcią rozpowszechnienia ujednoliconych śpiewów cerkiewnych wśród staroobrzędowców, A. Morozow przekazuje nieodpłatnie księgi kilkudziesięciu parafiom popowców, jednak i tu spotyka go niemałe rozczarowanie. Zdecydowana większość wspólnot nie wprowadziła śpiewników „redakcji morozowskiej" do użytku liturgicznego. Już sam fakt realizacji wydania przy jednoczesnym zaangażowaniu państwowych instytucji naukowych oraz Cerkwi w skazywał całe przedsięwzięcie na porażkę ${ }^{56}$. Wydane pod patronatem A. Morozowa śpiewniki, już na pierwszy rzut oka różniły się od większości staroobrzędowych rękopisów, co i w tym przypadku nie uszło uwadze środowisk staroobrzędowców. Nie zabrakło głosów krytycznych tak pod adresem śpiewników, jak i samego wydawcy. U źródeł owej krytyki stało nie tyle przywiązanie wspólnot staroobrzędowych do tradycji rękopiśmienniczej, co liczne niedoskonałości redakcyjne oraz błędy w druku. Wystąpienie błędów przy tak skomplikowanym wydaniu było po prostu nie do uniknięcia, z czego krytycy wydawania nie do końca zdawali sobie sprawę ${ }^{57}$. Do najczęściej spotykanych należą: 1) przesunięcia tekstu w stosunku do zapisu kriukowego 2) nieprawidłowe rozmieszczenie kinowarnych pomiet, bądź też ich brak. Tego typu niedociągnięcia, podobnie jak w przypadku rękopisów mogły skutkować nieprawidłową interpretacją samych melodii. Nasze zastrzeżenia budzi także pisownia formuł melodycznych zamkniętego charakteru (lic i fit), która w znaczącym stopniu odbiega od tej, zawartej w księgach rękopiśmiennych. Co więcej, lica i fity w większości wydrukowano w wersji zaszyfrowanej, co dodatkowo utrudnia ich prawidłowe wykonanie ${ }^{58}$. Odrębną kwestię stanowią niektóre warianty melodycz-

\footnotetext{
И. Дынникова, Морозовский хор..., dz. суt., s. 245.

Н. Денисов, Традиции старообрядческого иерковного пения. Певческие источники, praca dostępna na: http://www.portal-slovo.ru/ art/36005.php [15.10.2013].

58 И. Дынникова, Морозовский хор..., dz. cyt., s. 248.
}

ne śpiewów zamieszczone w „Cyklu”. Niektóre z nich, jak udało nam się ustalić, w znaczący sposób odbiegały od tych, zawartych w rękopiśmiennych śpiewnikach używanych przez wspólnoty popowców. Niewykluczone, iż przy realizacji wydania wykorzystano także inne, bliżej nieznane rękopisy „redakcji guslickiej”" W9. Wydaje się to o tyle prawdopodobne, sam Fortow pochodził bowiem z Guslic $^{60}$ - miejscowości położonej w Bogorodskim rejonie Rosji ${ }^{61}$. Ukazanie się drukiem pierwszego pełnego „Cyklu” staroruskich śpiewów cerkiewnych wywołało ożywioną dyskusję na temat kierunku rozwoju śpiewu cerkiewnego u staroobrzędowców ${ }^{62}$. Współczesny badacz staroruskiego śpiewu cerkiewnego - M. Brażnikow, poszedł o krok dalej i zanegował wartość melodii zawartych w "Cyklu”, uznając je za wytwór fantazji Fortowa ${ }^{63}$. Mimo wielu niedoskonałości „Cykl morozowski” nadal pozostaje ważnym źródłem dla dalszych badań nad stanem śpiewu liturgicznego u staroobrzędowców popowców w 2-giej połowie XIX wieku. Niewątpliwie stanowi dowód na to, jak daleko odstąpiono od wzorców melodycznych sprzed reform patriarchy $\mathrm{Ni}$ kona.

Znawcy staroruskiego śpiewu cerkiewnego końca XIX i początku XX wieku, w kwestiach związanych $\mathrm{z}$ jego rozwojem i popularyzacją podzielili się na zwolenników i przeciwników unifikacji repertuaru. Odgórne narzucenie poszczególnym parafiom staroobrzędowym określonego modelu śpiewu, wobec braku zorganizowanej władzy hierarchicznej stało się po prostu niemożliwym do zrealizowania. Co więcej, stwarzało realne niebezpieczeństwo zaistnienia rozłamu wewnątrz i tak podzielonych popowców. Na początku wieku XX dojdą do głosu stronnictwa, które opowiedzą się za ujednoliceniem zasad czytania kriuków przy jednoczesnym zachowaniu różnorodności form śpiewu. Obok tradycyjnego ośmiotrybowego ${ }^{64}{ }^{\text {}}$,znamiennago

59 Guslickie rękopisy muzyczne mają bogatą kolorystykę, dominują kolory: czerwony, żółty niebieski w dwóch zestawieniach: 1) żółty, czerwony, niebieski i zielony, 2) żółty i czerwony. Mniej więcej od końca 1-szej połowy XIX wieku, w zdobnictwie guslickim w miejsce koloru żółtego pojawia się złoty. Co więcej, obok typowych dla staroobrzędowych rękopisów muzycznych zastawek-ramek pojawiają się miniatury, przedstawiające np. Jezusa Chrystusa, św. Jana z Damaszku, św. Romana Piewca, bądź też inne postaci Świętych. Oprawy wszystkich rękopisów guslickich zostały kunsztowne wykonanie, głównie $\mathrm{z}$ cienkich deseczek obciągniętych skórą. W większości posiadają odciśnięte ornamenty pokryte złotem. Generalnie rękopisy powstałe wewnątrz wspólnot popowców stanowią przedłużenie tradycji 2-giej połowy XVII wieku. - Zob.: T. Владышевская, Музыкальная культура Древней Руси, Москва 2006, s. 242 ; Е. Бобков, Певческие рукописи гуслицкого письма, „Труды Отдела древнерусской литературы", 1977, Т. 32, s. 388.

60 Pierwsza historycznie potwierdzona wzmianka o wsi Guslica/Guslicy/Guslicie pojawia się w datowanej na ok. 1339 r. Duchownoj gramotie księcia Iwana Daniiłowicza Kality. Później zaś wspominają o niej gramoty książąt: Dymitra Iwanowicza z 1389 r., księcia halickiego Jurija Dmitrijewicza z 1433 r., Iwana III z 1504 r. - Zob.: Духовные и договорные грамоты великих и удельных князей XIV-XVI вв, Москва-Ленинград 1950, s. 7-8, 34, 74, 360, 424, 434.

61 Współcześnie południowa cześć rejonu Oriechowo-Zujewo.

62 Zob.: Г-въ, «Хомовое» или «наречное, „Церковное пение”, 1909, № 8, s. 211-224.

63 М. Бражников, Лица и фиты знаменного распева, Ленинград 1984, s. 12-13.

64 Spiew „ośmiotrybowy”, czyli oparty na zasadzie „ośmiu skal modalnych” (cs. osmogłasija). W dostępnej w Polsce literaturze tematu występuje 
raspiewa" oraz melizmatycznego śpiewu demestwennego, staroobrzędowcy zaczną doceniać walory estetyczne i duchowe miejscowych wariantów śpiewu, które cechowała większa swoboda kompozycji. Do takich melodii $\mathrm{z}$ pewnością należy zaliczyć tzw. śpiew irgizki ${ }^{65}$ (irgizskij napiew $)^{66}$. Tego typu kompozycje tzw. podobnie jak wiele innych jednogłosowych melodii cerkiewnych, pozostających w użytku liturgicznym u staroobrzędowców popowców, przez długi czas były uważane za obce. Aczkolwiek już na początku XX wieku, stanowisko staroobrzędowców wobec tego, i innych nowych napiewów ulegnie stopniowej liberalizacji. Jako ciekawostkę należy podać fakt, iż popowcy zamieszkujący terytoria Rumunii oraz Ukrainy po dziś dzień praktykują wiele wariantów melodycznych Pieśni Cherubinów, w szczególności mam tu na myśli dostosowane do wymogów starego tekstu liturgicznego śpiewy bułgarskie ${ }^{67}$ i kijowskie, które i tu niespodzianka, zapisywano za pomocą staroruskiej notacji kriukowej. W tym konkretnym przypadku można mówić o wzajemnym przenikaniu się wpływów moskiewskich i kijowskich. Zjawisko da się zaobserwować wśród staroobrzędowców zamieszkujących terytorium dzisiejszej Ukrainy, Mołdawii oraz Rumunii ${ }^{68}$.

Omówiony w pierwszej części pracy „Cykl” staroruskich śpiewów cerkiewnych był niewątpliwie urzeczywistnieniem wielowiekowych dążeń, zmierzających do wydania drukiem śpiewników zawierających kriuki. Mimo, iż po dziś dzień nie doczekał się oficjalnego uznania wspólnot staroobrzędowców, z pewnością należy go uznać za pierwszą, bądź co bądź nieudaną, próbę uporządkowania wykonywanego w cerkwiach popowców repertuaru.

Brak ujednoliconych śpiewników, niekiedy szedł $\mathrm{w}$ parze $\mathrm{z}$ różnorodnością pojmowania teorii staroruskiego śpiewu cerkiewnego. Wprowadzenie w XVII wieku do staroruskiej notacji kriukowej systemu znaków pomocniczych (tzw. kinowarnych pomiet) wprawdzie wpłynęło na ujednolicenie pojmowania teorii śpiewu ${ }^{69}$, aczkolwiek w większości podręczników powstałych w środowiskach

ponadto pojęcie śpiewu „ośmiogłosowego”. Niekiedy pojęcie to może być zrozumiane jako śpiew wykonywany na osiem partii głosowych. Por. U. Wójcicka, Wariacje na temat muzyki (Próba usystematyzowania staroruskich motywów muzycznych w literaturze XI-XV wieku), „Musica Antiqua Europae Orientalis", T. VII, Bydgoszcz 1985, s. 47-48.

65 Określenie pochodzi od nazwy czołowego ośrodka staroobrzędowców popowców, znajdującego się nad rzeką Irgiz.

${ }_{66} \mathrm{~W}$ staroruskiej cerkiewnej terminologii muzycznej, obok terminu raspiew, funkcjonuje termin napiew, który oznacza wariant melodyczny danego raspiewa. Niekiedy w skład jednej skali modalnej danego raspiewa może wchodzić po kilka, a nawet kilkanaście napiewow. Termin napiew może niekiedy wskazywać na regionalny charakter danej melodii, np. śpiew wołyński (wołynskij napiew), jabłoczyński, leśniański i inne. И. Вознесенский, О церковном пении..., dz. суt., s. 95-97, por. D. Sawicki, Staroruski śpiew cerkiewny i funkcjonowanie jego wybranych form w praktyce liturgicznej staroobrzędowców, Warszawa 2013 (rozprawa doktorska w ChAT), s. 31.

67 Melodia bułgarska Pieśni Cherubinów w przyszłości znajdzie się w zrealizowanym 1909 r. przez Ł. Kałasznikowa wydaniu Obiednicy. Zob.: Обеднииа знаменнаго и демественнаго роспева съ архиерейскимг служениемъ, изд. 1, Киев 1909, k. 82-83.

68 Zob.: Е. Поспелов, О новых напевах, „Церковное пение”, 1909, № 4-5, s. $92-98$

69 D. Sawicki, Pierwsze próby..., dz. cyt., s. 144. staroobrzędowców znajdziemy elementy, stanowiące bardziej punkt widzenia ich autorów, niż ogólnie obowiązujące zasady czytania kriuków ${ }^{70}$. Co więcej, większość wspólnot staroobrzędowych niemal do końca XIX wieku zasady czytania kriuków przekazywała ustnie ${ }^{71}$.

Sytuacja uległa stopniowej zmianie w 1908 roku, za sprawą wybitnego znawcy staroruskiego śpiewu cerkiewnego - kijowskiego staroobrzędowca Łazarza Kałasznikowa $^{72}$. Wówczas ukazał się drukiem Podręcznik śpiewu neumatycznego (Azbuka cerkownogo znamiennogo pienija) autorstwa Kałasznikowa. Wydanie niemal od razu wywołało żywe zainteresowanie środowisk staroobrzędowych zarówno tych w Rosji, jak i na emigracji ${ }^{73}$. Wśród wielu opinii środowisk zajmujących się śpiewem pojawiały się także głosy krytyki, i dotyczyły nie tyle treści samej Azbuki, co niektórych kwestii metodologicznych. Otóż w swojej Azbuce Kałasznikow wyjaśnił znaczenie muzyczne poszczególnych neum przy pomocy wartości liczbowych, odpowiadających długości brzmienia $(4 / 4,1 / 2,1 / 4,1 / 8)^{74}$, co stanowiło zerwanie z tradycją XVI-XVII wiecznych Azbuk tołkowanij, gdzie znaczenie prostych znaków wyjaśniano w sposób opisowy, bądź też przy pomocy kwadratowej notacji kijowskiej ${ }^{75}$. Znaczenie znaków złożonych melodycznie, Kałasznikow wyjaśnił przy pomocy prostych znaków (kriuka, stopicy, zapiatoj), czym niewątpliwie chciał nawiązać do XIX-wiecznych traktatów staroobrzędowych ${ }^{76}$. Wzorem autorów starych XVI-XVII wiecznych Azbuk, Kałasznikow nie zamieszcza żadnych instrukcji, dotyczących zasad operowania głosem. Zainteresowanych odesłał do aktualnie obowiązujących podręczników ${ }^{77}$ (wskazując na ówcześnie obowiązującą manierę bel canto $)^{78}$. Wychodząc z założenia,

\footnotetext{
70 Tenże, Staroje istinnorieczije..., dz. cyt., s.172.

71 Н. Денисов, Стрельниковский хор Костромской земли. Традииии старообрядческого иерковного пения, Москва 2005, s. 109.

72 „Церковь”, Москва 1908, s. 1444.

73 Азбука иерковного знаменного пения, Кіев 1908.

74 Tamże, s. 3.

75 W staroruskim bezpomietnym zapisie neumatycznym poszczególne
} znaki (znamiona in. kriuki) nie wskazywały w sposób bezpośredni na wysokość dźwięku, lecz koncentrowały się głównie na ukazaniu danego interwału - odległości pomiędzy dźwiękami oraz sposób wykonania danej frazy melodycznej, długość brzmienia dźwięku oraz rytm. Umowność znaczenia staroruskich neum sprawiała, iż śpiewacy pozwalali sobie na coraz to większą swobodę w ich interpretacji, co niekiedy zniekształcało melodie. К. Никольская-Береговская, Русская вокально-хоровая школа IX-ХХ веков, Методическое пособие, Москва 1998, s.12, 14. W jednej z XVI wiecznych Azbuk ze zbiorów monasteru Sołowieckiego czytamy: „, Крюк - възгласит мало выш строк. А мрачныи - мало выш простаго. А светлый - мрачнаго выш. А тресветлый - светлаго выше. Аще л тресветлый с сорочею ножкою - велми пак возгласит...” РГБ, Сол. Собр. 277/283, s. 252. Суt. za: Д. Шабалин, Певческие азбуки древней Руси, Т. I, Краснодар 2004, s. 63.

76 М. Озорнов, Азбука крюкового пения, Москва 1901.

77 Ł. Kałasznikow mógł mieć na myśli m.in. publikacje autorstwa ks. W. Mietałłowa. Zob.: В. Металлов, Азбука крюкового пения, Москва 1899 ; Осмогласие знаменнаго росппва. Опьт руководства къ изучению осмогласія знаменнаго роспгва по гласовымъ попьвкам, Москва 1899. 78 Belcanto (in. Bel canto) - włoska technika wokalna, której fundamentem jest umiejętność posługiwania się oddechem, połączenie rezonansu głowy i piersi, co pozwala na lekkie i miękkie, naturalne pasaży, tryli i innych ornamentów, skoki melodii, zróżnicowaną artykulację. Technikę belcanta doprowadzili do szczytu włoscy kastraci i włoskie śpiewaczki operowe. Por. J. Ekiert, Bliżej muzyki. Encyklopedia, Warszawa 1994, s. 50. 
iż aspektów czysto wykonawczych nie da się tak po prostu opisać słowami, ich przekazanie autor pozostawił w gestii nauczycieli ${ }^{79}$. Z czasem, każdy uczeń wypracowywał własną, mniej lub bardziej prawidłową manierę wykonawczą. Niekiedy narzucała ją sama wspólnota, w której dany uczeń pobierał naukę przy okazji zdobywając odpowiednią praktykę liturgiczną. Opracowana przez Kałasznikowa Azbuka doczekała się kilku reedycji, z których ostatnia ukazała się drukiem w $1915 \mathrm{r}$.

Oprócz podstawowego modelu staroruskiego śpiewu cerkiewnego - znamiennago raspiewa, w praktyce liturgicznej staroobrzędowców wszystkich konfesji, funkcjonowały bardziej złożone melodycznie śpiewy, w szczególności śpiew demestwenny (diemiestwiennoje pienije) wraz jego notacją. Mimo. iż tradycja śpiewania diemiestwom przeżywała w 2-giej połowie XIX wieku swój prawdziwy rozkwit, to w wielu wspólnotach staroobrzędowców-popowców śpiew ten pełnił drugorzędną rolę. Był to efekt jego bardzo złożonej melodyki oraz braku jednolitych zasad czytania neum (tzw. kliuczewych znamion) ${ }^{80}$. Wychodząc naprzeciw zainteresowaniom środowisk staroobrzędowych śpiewem demestwennym, Kałasznikow wydaje w 1911 roku Podrecznik śpiewu demestwennego ${ }^{81}$. Na materiał źródłowy potrzebny do realizacji wydania, jak ustaliła G. Pożidajewa składało się sześć rękopisów, z których w każdym $\mathrm{z}$ nich znaczenie poszczególnych znaków notacji demestwennej przedstawiono przy pomocy prostych znaków notacji kriukowej, co najbardziej najbardziej inspirowało Kałasznikowa ${ }^{82}$. W przedmowie do I wydania Azbuki czytamy: „Pośród miłośników śpiewu cerkiewnego, w ostatnim czasie coraz częściej przychodzi się słyszeć narzekania na śpiewaków-profesjonalistów, którzy podczas nabożeństw prawie wcale nie stosują śpiewu demestwennego..." ${ }^{83}$. W tej konkretnej kwestii Kałasznikow minął się z prawdą, bowiem śpiew demestwenny od zawsze funkcjonował w praktyce liturgicznej wspólnot staroobrzędowych i to zarówno popowców, jak też bezpopowców. Aczkolwiek i w tym przypadku, wydanie Azbuki należy uznać za jak najbardziej uzasadnione.

\footnotetext{
79 И. Гарднер, Богослужебное пение..., Т. II, dz. cyt., s. 470-471.

80 Г. Пожидаева, Лексикология демественного пения, Москва 2010, s. $65-68$.

81 Pierwszy spis znaków notacji demestwnnej opublikował ks. D. Razumowski, jako dodatek do dzieła pracy pt. Śpiew cerkiewny w Rosji.

82 Г. Пожидаева, Лексикология демественного..., dz. суt., s. 249.

83 Cуt. za: Азбука демественного пения, Кіев, 1911.
}

W 1908 roku, tóż przed ukazaniem się pierwszego wydania Azbuki, Ł. Kałasznikow zakłada w Kijowie własne wydawnictwo pod nazwą: „Znamiennoje Pienije”. Jak na owe czasy było to śmiałe, ale także ryzykowne posunięcie. Normalne funkcjonowanie wydawnictwa $\mathrm{z}$ całą pewnością byłoby niemożliwe, gdyby nie Ukaz tolerancyjny Mikołaja II ogłoszony w 1905 r. Dokument dawał staroobrzędowcom wszystkich konfesji gwarancję swobodnego wyznawania wiary, w tym także budowania świątyń, zakładania szkół oraz prowadzenia działalności wydawniczej. Nie bezpodstawnie okres od 1905 do 1917 roku określany jest mianem „złotego wieku starego obrzędu" ${ }^{\text {. }}$. 
$n y)^{90}$. Dla celów dydaktycznych, Kałasznikow opracował tzw. Oktoich szkolny (Oktaj Uczebnyj), który obok Azbuk, stał się podstawowym podręcznikiem do nauki śpiewu ${ }^{91}$. $\mathrm{W}$ realizację swoich przedsięwzięć wydawniczych $Ł$. Kałasznikow zainwestował niemały kapitał, czym wiele ryzykował, zważywszy na to jaki los spotkał inicjatywę A. Morozowa. Wydawca zdawał sobie sprawę, iż jego wydania może spotkać taki sam los. Aczkolwiek w tym konkretnym przypadku stało się inaczej.

Jak podają dokumenty, 27 sierpnia 1910 roku podczas jednego z posiedzeń Świętego Soboru Rosyjskiej Prawosławnej Cerkwi Staroobrzędowej (Białokrynickiej Hierarchii) ${ }^{92}$ Ł. Kałasznikow wystąpił $\mathrm{z}$ wykładem na temat realizowanych przez siebie przedsięwzięć wydawniczych. Prosząc o poparcie wskazywał na pilną potrzebę druku kriukowych ksiąg liturgicznych, co w jego ocenie, w przyszłości mogło zaowocować podniesieniem poziomu praktykowanego przez poszczególne parafie śpiewu cerkiewnego. Postulat Kałasznikowa zyskał pełną aprobatę członków Soboru, po czym arcybiskup moskiewski Jan (1898-1915) udzielił wydawcy błogosławieństwa na wydawanie i sprzedaż kriukowych ksiąg liturgicznych. Potwierdzając swoim podpisem zgodność wydawanych śpiewników z rękopisami znajdującymi się w posiadaniu biblioteki Cmentarza Rogożskiego w Moskwie, abp Jan zobowiązał wydawcę do dostarczania $\mathrm{w}$ celu zatwierdzenia próbnych egzemplarzy każdego śpiewnika ${ }^{93}$. W tym miejscu należy zaznaczyć fakt, iż Cmentarz Rogżoski w Moskwie, od momentu powstania, czyli od XVIII wieku, stał się wiodącym centrum stroobrzędowców popowców. Co więcej, jest on jednym z nielicznych w Rosji ośrodków staroobrzędowców, gdzie pomimo utrudnień ze strony władz carskich niemal nieprzerwanie sprawowano nabożeństwa ubogacane śpiewem, zatem i śpiew liturgiczny na cmentarzu Rogożskim stał na bardzo wysokim poziomie. Na przełomie XIX i XX wieku działało tam wielu znakomitych śpiewaków, w szczególności: M. Ozornow, I. Fortow oraz J. Bogatienko - teoretyk śpiewu autor wielu artykułów zamieszczonych na łamach starobrzędowych czasopism, w szczególności „Cerkownogo Pienija"s. Na przełomie XIX i XX wieku przodowały

\footnotetext{
90 Трезвоны, Москва 1914.

91 Н. Денисов, Стрельниковский хор..., dz. cyt., s. 116.

92 Staroobrzędowcom od samych początków istnienia Raskołu doskwierał brak wyższej hierarchii duchownej. Wszelkie próby pozyskania biskupa, jakie popowcy podejmowali w XVIII wieku kończyły się niepowodzeniem. Pojawiali się wprawdzie w większości fałszywi biskupi (ros. łżejepiskopy), którzy przy pomocy sfałszowanych dokumentów o otrzymanych święceniach zyskiwali poparcie staroobrzędowców wyświęcając dla nich duchownych. Jednakże myśl o pozyskaniu biskupa wyświęconego wedle starych obrzędów pozostawała wciąż żywa. W wyniku licznych starań w 1846 r. popowcom zamieszkałym na terenie państwa austriackiego, ściślej Bukowiny, udało się pozyskać i sprowadzić z Konstantynopola pozbawionego katedry metropolitę bośniackiego Ambrożego, który to dał początek tzw. białokrynickiej hierarchii. Struktura ta istnieje do dnia dzisiejszego z siedzibą na Cmentarzu Rogożskim w Moskwie. - Zob.: E. Iwaniec, $Z$ dziejów staroobrzędowców na ziemiach polskich XVII-XX w., Warszawa 1977, s. 49.

93 Освященньй собор старообрядческих епископов. Третий день, „Церковь”, 1910, nr 36, s. 891

94 Я. Богатенко, Методика церковного пения, „Церковь”, 1909, № 19, s. 636-637; № 40, s. 1145-1152; № 48, s. 1348-1350.
}

w Moskwie dwa staroobrzędowe chóry, tj. chór wspólnoty Rogożskiej pod kierownictwem J. Bogatienko oraz słynny chór Morozowski, działający pod kierownictwem P. Cwietkowa ${ }^{95}$. Ośrodek posiadał bardzo bogatą bibliotekę, którą skonfiskowano w 1918 roku $^{96}$. W zasobach biblioteki znajdowało się wiele cennych rękopisów muzycznych ${ }^{97}$. Wszystko wskazuje na to, iź źródła wykorzystane do realizacji wydania pochodziły właśnie ze zbiorów biblioteki Cmentarza Rogożskiego. Gdyby tak nie było, to arcybiskup moskiewski Jan z całą pewnością nie poświadczyłby zgodności wydawanych ksiąg z rękopisami znajdującymi się w zbiorach tejże biblioteki. Poparcie władz cerkiewnych dawało Kałasznikowowi gwarancję zbytu, co znalazło przełożenie na nakład wydawanych ksiąg. Nakład jednej pozycji wydawniczej, według naszych ustaleń wahał się od tysiąca do dwóch, czasem także i trzech tysięcy egzemplarzy. Swoje śpiewniki Kałasznikow drukował techniką litograficzną, która była znacznie tańsza od druku z zastosowaniem ruchomych czcionek, co dodatkowo zminimalizowało ryzyko wystąpienia błędów w druku.

W międzyczasie, w Moskwie swoje własne wydawnictwo zakłada M. Ozornow, który m.in. wydaje własny podręcznik do nauki śpiewu neumatycznego ${ }^{98}$. Wzorem kijowskiego "Znamiennogo Pienija”, wydawnictwo Ozornowa również posiadało własną drukarnię, którą kierował niejaki N. Kruczkow. Jako ciekawostkę należy podać fakt, iż Kruczkow jako pierwszy zastosował do druku kriukowych śpiewników ruchome czcionki, co poprawiło jego jakość, przy okazji podnosząc niemal o połowę koszty, co przy niskim nakładzie czyniło druk śpiewników całkowicie nieopłacalnym ${ }^{99}$. Inicjatywa wydawnicza Ozornowa nie wytrzymała jednak ostrej konkurencji ze strony kijowskiego "Znamiennogo Pienija”. Normalnie wydawnictwu Ozornowa groziło zamknięcie, lecz konflikt Kałasznikowa z miejscowymi władzami Kijowie, które zarzucały mu oszustwa podatkowe oraz zaniżanie deklarowanych cen ksiąg sprawił, iż na przełomie 1912 i 1913 r. obaj wydawcy połączyli siły. Kałasznikow wniósł do spółki olbrzymi kapitał finansowy i wiedzę w zakresie drukowania śpiewników, Ozornow zaś unowocześnione prasy drukarskie oraz ruchome czcionki zawierające kriuki. Nowe wydawnictwo działało w Moskwie do 1918 roku pod nazwą „Znamiennoje Pienije”. Połączenie obydwu wydawnictw oraz udoskonalenie druku zaowocowało zwiększeniem nakładu, co znalazło swoje przełożenie na cenę detaliczną ksiąg. Kriukowe śpiewniki z dnia na dzień stały się dostępne dla każdej parafii oraz niezamożnych śpiewaków, dla których posiadanie własnych ksiąg oznaczało pewnego rodzaju prestiż ${ }^{100}$.

Aby ułatwić dystrybucję wydawanych przez siebie śpiewników oraz materiałów dydaktycznych, Kałasznikow

\footnotetext{
95 Н. Денисов, Стрельниковский хор..., dz. суt., s. 196.

96 Obecnie zbiory biblioteczne Cmentarza Rogożskiego w Moskwie znajdują się we władaniu Rosyjskiej Biblioteki Państwowej w Moskwie (nr zespołu 247).

97 Н. Денисов, Стрельниковский хор..., dz. суt., s. 21.

98 Zob.: przyp. 76.

99 „Церковь”, Москва 1912, № 31, s. 759.

100 Ф. Мельников, Краткая история..., dz. суt., s. 468.
} 
w 1909 roku rozpoczął wydawanie miesięcznika „Cerkownoje Pienije", które od 1910 do 1918 roku dołączano do czasopisma „Staroobriadczeskaja Mysl”. Dla prenumerujących miesięcznik, wydawca stosował zniżki przy zakupie ksiąg, co dodatkowo skutkowało podniesieniem sprzedaży. Na lamach czasopisma omawiano liczne problemy z zakresu historii i teorii staroruskiego śpiewu cerkiewnego. Niekiedy dyskusje przybierały burzliwą formę, szczególnie w kwestiach dotyczących praktyk śpiewaczych poszczególnych wspólnot staroobrzędowych. Autorami zamieszczanych na łamach „Cerkownogo Pienija” tekstów byli dyrygenci i śpiewacy cerkiewni, w szczególności: J. Pospiełow, Ł. Bystrow, J. Bogatienko oraz P. Cwietkow. Z redakcją stale współpracował St. Smoleński, którego cykliczne artykuły z dziedziny historii i teorii śpiewu cieszyły się wśród staroobrzędowców wielką popularnością, zaś sam autor nie krył także swojej sympatii dla tejże grupy wyznawców prawosławia ${ }^{101}$.

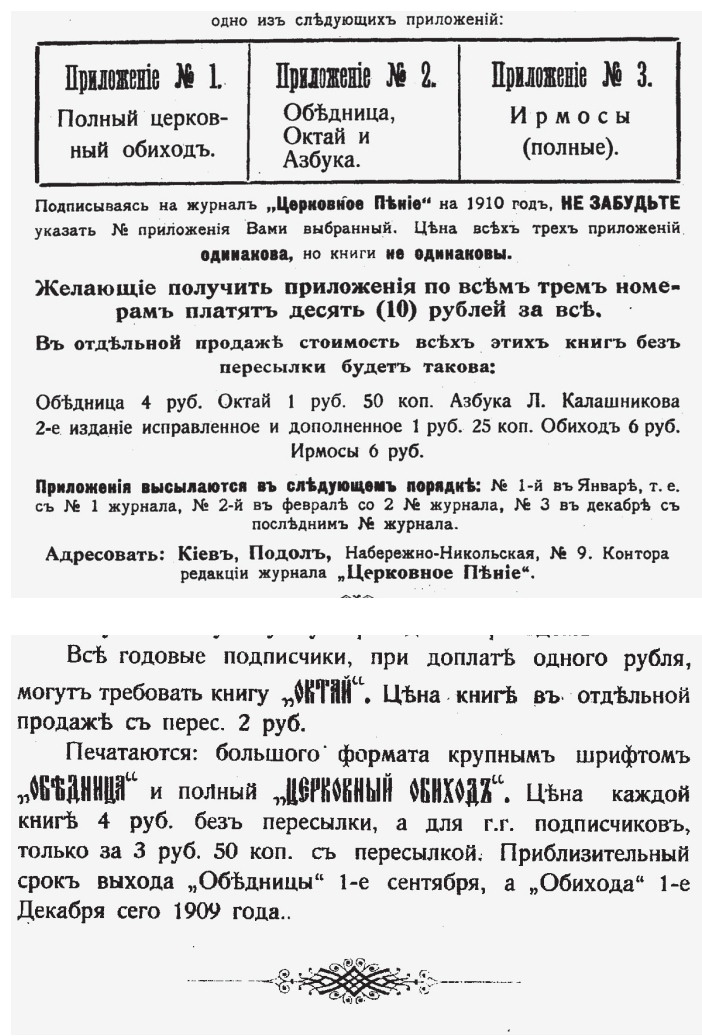

Oferta sprzedaży ksiąg wydawanych przez Kałasznikowa zamieszczona w 1909 r. na łamach czasopisma „Cerkownoje Pienije”

Kriukowe księgi liturgiczne wydawane przez oficynę Ł. Kałasznikowa, podobnie jak wcześniej „Cykl” A. Morozowa, spotkały się ze zróżnicowanym przyjęciem ze strony wspólnot staroobrzędowych. Na nowo rozgorzała polemika o sens używania drukowanych śpiewników tak

\footnotetext{
101 Zob.: Ст. Смоленский, Об указаниях оттенков исполнения и указаниях музыкально-певческих форм в крюковом письме, „Церковное пение”, 1909, №3, s. 65-83; № 12, s. 314-317.
}

w codziennej praktyce liturgicznej, jak i w celach dydaktycznych ${ }^{102}$. Zarzuty kierowane pod adresem wydawnictw Kałasznikowa były niemal identyczne, jak w przypadku przedsięwzięcia A. Morozowa. Szczególnie krytykowano „kałasznikowskie” Irmosy, gdzie faktycznie można znaleźć pewne nieścisłości w rozmieszczeniu niektórych znaków ${ }^{103}$. Co więcej, podważano prawidłowość rękopisu, którym posłużył się wydawca ${ }^{104}$. W uzyskaniu aprobaty staroobrzędowych w Rosji jak i na emigracji nie pomogło nawet poparcie władz cerkiewnych w Moskwie. Szczególny dystans w stosunku do ksiąg drukowanych zachowywali popowcy zamieszkujący terytoria między Dniestrem a Prutem (tzw. Besarabii) oraz Ukrainy. Ci, kultywowali własne regionalne warianty śpiewu, w wielu aspektach różniące się od praktykowanych w Rosji ${ }^{105}$. Sytuacja uległa zmianie po 1945 roku, kiedy to wskutek zawirowan politycznych parafie staroobrzędowe znajdujące się na terytoriach Besarabii przeszły pod jurysdykcję arcybiskupstwa w Moskwie, co ukróciło ich kontakty ze współwyznawcami mieszkającymi w Rumunii. Parafiom położonym na terytorium Mołdawii i Ukrainy zaczęto niejako narzucać warianty śpiewu praktykowane na cmentarzu Rogożskim w Moskwie, gdzie wówczas śpiewano głównie ze śpiewników Kałasznikowa. Wszelkie próby narzucenie „kałasznikowskiego” stylu śpiewu spotkało się ostrym sprzeciwem tak ze strony duchowieństwa, jak i wiernych ${ }^{106}$.

Przytoczone w niniejszej pracy staroobrzędowe wydania kriukowych ksiagg liturgicznych, mimo upływu lat nie straciły na wartości, a po dziś dzień są wykorzystywane są w praktyce liturgicznej popowców ${ }^{107}$. Współcześnie za najbardziej wiarygodne, staroobrzędowcy uznają wydania Ł. Kałasznikowa, które po upadku ZSRR doczekały się szeregu przedruków. Co do wydań A. Morozowa, to niechęć do nich utrzymała się w środowiskach staroobrzędowych do dnia dzisiejszego. O ile w XIX w. jej źródłem był fakt, iż wydanie zrealizowano przy poparciu „oficjalnej Cerkwi”. O tyle współcześnie, środowiska śpiewaków, i to nie tylko staroobrzędowców wskazują na szereg niedoskonałości redakcji. Reasumując, zarówno „Cykl” A. Morozowa, jak również wydania $€$. Kałasznikowa, nadal pozostają bogatym źródłem dla dalszych badań nad dziejami staroruskiego śpiewu cerkiewnego, a w szczególności śpiewu staroobrzędowców. Szczegółowa analiza wybranych śpiewów, zawartych w obydwu cyklach będzie przedmiotem naszych kolejnych prac.

\footnotetext{
102 Н. Зенин, Как еще далеко до рассвета, „Старообрядческая мысль”, 1911, № 6, s. 499, por. И. Дынникова, Морозовский хор..., dz. cyt., s. 79

103 Tamże, s. 246-247

104 Е. Поспелов, Мои заметки, „Старообрядческая мысль”, (Приложение: Церковное пение), 1910, № 8, s. 137.

105 Е. Смилянская, Н. Денисов, Старообрядчество Бессарабии: книжность и певческая культура, Москва 2007, s. 51.

106 Tamże, s. 52.

107 Н. Денисов, Стрельниковский хор..., dz. суt., s. 129.
} 


\section{Bibliografia}

\section{Źródła}

Ірмологіон нотный, Львов 1700.

Ірмологіон нотный, Львов 1709.

Духовные и договорные грамоть великих и удельных князей XIV-XVI в6, Москва-Ленинград 1950.

Ирмосы, Кіев 1909-1912.

Круг церковного древнего знаменного пения, Ч. 1, Санкт-Петербург 1884.

Обеднииа знаменнаго и демественнаго роспева съ архиерейскимъ служениемъ, изд. 1, Киев 1909.

Обиходъ иерковнаго знаменнаго пения, изд. 1, Киев 1909.

Октай иерковнаго крюковаго пения, изд. 1, Киев 1909.

Освященный собор старообрядческих епископов. Третий день, „Церковь”, 1910, nr 36.

Праздники, Кіев 1910.

Трезвоны, Москва 1914.

\section{Opracowania}

Ekiert J., Bliżej muzyki. Encyklopedia, Warszawa 1994.

Florczak M., Śpiewy liturgiczne Rosyjskiej Cerkwi prawosławnej, zarys historyczno-analityczny, Warszawa 2013

Iwaniec E., Z dziejów staroobrzędowców na ziemiach polskich XVII -XX w., Warszawa 1977.

Jaroszewicz-Pieresławcew Z., Druki cyrylickie z oficyn Wielkiego Księstwa Litewskiego w XVI-XVIII wieku, Olsztyn 2003.

Jasinowśkyj J., Znaczenie eparchii Przemyskiej w rozwoju ukraińskiej muzyki cerkiewnej, [w:] Polaska-Ukraina 1000 lat sąsiedztwa, red. S. Stępień Przemyśl 1994, T. II, s. 403-420.

Lissa Z., Historia Muzyki Rosyjskiej, Warszawa 1955.

Pidłypczak-Majerowicz M., Bazylianie w Koronie i na Litwie. Szkoły i książki w działalności zakonu, Warszawa - Wrocław 1986.

Przywecka-Samecka M., Dzieje drukarstwa muzycznego w Polsce do końca XVIII wieku, Wrocław 1993.

Sawicki D., Kwestia „razdielnorieczija” $i$ śpiewu wielogłosowego $w$ nauczaniu staroobrzędowców rosyjskich, ELPIS, t. 16, s. 201-209.

Sawicki D., Pierwsze próby reform śpiewu cerkiewnego na Rusi. Działalność I i II Komisji (1652-1670), ELPIS, Rocznik XV (XVI), Zeszyt 27(40), s. 139-146.

Sawicki D., Staroje istinnorieczije $i$ razdielnorieczije jako dwie główne epoki w dziejach śpiewu liturgicznego na Rusi od XI w. do XVII w., [w:] „Z badań nad językiem i kulturą Słowian”, red. P. Sotirov i P. Złotkowski, Lublin 2007, s. 169-178.

Sawicki D., Staroruski śpiew cerkiewny i funkcjonowanie jego wybranych form $w$ praktyce liturgicznej staroobrzędowców, Warszawa 2013 (rozprawa doktorska w ChAT), s. 31.

Wójcicka U., Wariacje na temat muzyki (Próba usystematyzowania staroruskich motywów muzycznych $w$ literaturze XI-XV wieku), „Musica Antiqua Europae Orientalis”, T. VII, Bydgoszcz 1985, s. 47-68.

Wołosiuk W., Irmologion Supraski, „Rocznik Teologiczny”, rok. XLVI, Warszawa 2004/2.

Wołosiuk W., Wschodniosłowiańscy kompozytorzy muzyki cerkiewnej od XVII do 1. połowy XX wieku i obecność ich utworów w nabożeństwach PAKP, Warszawa 2005.
Wołosiuk W., Wschodniosłowiańskie pieśni religijne. Ich geneza, struktura oraz zarys rozwoju, Warszawa 2013.

Бобков Е., Певческие рукописи гуслицкого письма, „Труды Отдела древнерусской литературь”, 1977, Т. 32, s. 388-394.

Богатенко Я., Методика иерковного пения, „Церковь”, 1909, № 19, s. 636-637; № 40, s. 1145-1152; № 48, s. 1348-1350.

Бражников М., Лица и фиты знаменного распева, Ленинград 1984.

Бражников М., Русская певческая палеография, Санкт-Петербург 2002.

Бражников М., Лица и фиты знаменного распева, Ленинград 1984ю

Бычков В., Русская средневековая эстетика XI-XVII века, Москва 1995, s. 543-588.

Владышевская Т., Музыкальная культура Древней Руси, Москва 2006.

Вознесенский И., О церковном пении Православной Греко-Российской Церкви: Большой и малый знаменный роспев, Рига, 1890.

Вознесенский И., Церковное пение православной юго-западной Руси по нотолинейныь ирмологам XVII и XVIII веков, Вып. 1, Москва 1898.

Гарднер И, Богослужебное пение Русской Православной Церкви, Т. I-II, Москва 2004.

Г-въ, «Хомовое» или «наречное, „Церковное пение”, 1909, № 8, s. 211-224.

Григорьев Е., Пособие по изучению изерковного пения и чтения, Рига 2001.

Д. Шабалин, Певческие азбуки древней Руси, Т. I, Краснодар 2004.

Денисов Н., Стрельниковский хор Костромской земли. Традиции старообрядческого церковного пения, Москва 2005.

Денисов Н., Традиции старообрядческого иерковного пения. Певческие источники, praca dostępna na: http://www.portal-slovo.ru/art/36005.php [15.10.2013].

Дьнникова И., Морозовский хор в контексте старообрядческой культуры начала ХХ века, Москва 2009.

Зенин Н., Как еще далеко до рассвета, „Старообрядческая мысль", 1911, № 6.

Калашников Л., Азбука церковного знаменного пения, Кіев 1908.

Калашников Л., Азбука демественного пения, Кіев, 1911.

Келдыш Ю., История русской музыки, Т, І, Мосва 1983.

Кудрик Б., Огляд історії української иерковної музики, Львів 1995.

Кутузов Б., Русское знаменное пение, Москва 2008.

Лабынцев Ю., Памятники древнерусской книжности и титературы в старообрядческих изданиях Супрасльской типографии (ХVIII в.) „Труды Отдела древнерусской лиmературь" 1981, Т. 36, s. 209-215.

Мартынов В., История богослужебного пения, Москва 1994.

Мезенец А., Извещение о согласнейших пометах, изд. Ст. Смоленский, Казань 1888.

Мельников Ф., Краткая история древлеправославной (старообрядческой) Церкви, Барнаул, 1999. 
Металлов В., Азбука крюкового пения, Москва 1899.

Металлов В., Осмогласие знаменнаго росппва. Опьт руководства къ изучению осмогласія знаменнаго роспюва по гласовымъ поптвкам, Москва 1899.

Металлов В., Очерк истории Православнаго иерковнаго Пения, Москва 1915.

Модест арх., О иерковном октоихе, Вильна 1865.

Никольская-Береговская К., Русская вокально-хоровая школа IX-ХХ веков, Методическое пособие, Москва 1998.

Озорнов М., Азбука крюкового пения, Москва 1901.

П. Бессонов, Судьба нотных певческих книг, „Православное Обозрение», 1864, Т. XIV, s. 27-130.

Печенкин Г., Возвашник: Возвахи знаменного роспева: Обиходное осмогласие: Опыт исследования, истолкования, практики знаменного пения и методика обучения, Москва 2010.

Пожидаева Г., Лексикология демественного пения, Москва 2010.

Поспелов Е., Мои заметки, „Старообрядческая мысль”, (Приложение: Церковное пение), 1910, № 8.

Поспелов Е., Крюковое осмогласие, „Церковное Пение”, 1909, nr 1, s. 10-18.

Поспелов Е., О новых напевах, „Церковное пение”, 1909, № 4-5, s. 92-98.
Преображенский А., Разумовский, Димитрий Васльевичъ, „Русская Музыкальная Газета”, 1897, s. 622-623.

Разумовский Д., Богослужебное пение Православной Греко-Российской Церкви. Москва 1886.

Разумовский Д., О знаменном роспеве, [w:] Круг церковного древнего знаменного пения, Ч. 1, Санкт-Петербург 1884, s. X-XXIII.

Разумовский Д., Церковное пение в России, Москва 1867-69.

Сахаров И., Исследования о русском иерковном песнопении, „Журнал Министерства Народного Просвещения”, Вып. LXI-LXII, 1849, s. 146-196, 262-284.

Смилянская Е., Денисов Н., Старообрядчество Бессарабии: книжность и певческая культура, Москва 2007.

Смоленский Ст., Об указаниях оттенков исполнения и указаниях музыкально-певческих форм в крюковом письме, „Церковное пение”, 1909, №3, s. 65-83; № 12, s. 314-317.

Смоленский Ст., Примечания къ Азбуке Мезения, Казань 1888.

Тальберг Н., История русской церкви, Москва 2004.

Финдейзен Н., протоіерей Д. В. Разумовский (Очерк его деятельности), „Русская Музыкальная Газета”, 1894, nr 9, s. $173-178$.

Ясіновський Ю., Візантійська гимнограбія і иерковна монодія в українськой рецепції ранньо-модерного часу, Львів 2011.

Rozmiar artykułu: 1,2 arkusza wydawniczego 
ISSN 1508-7719

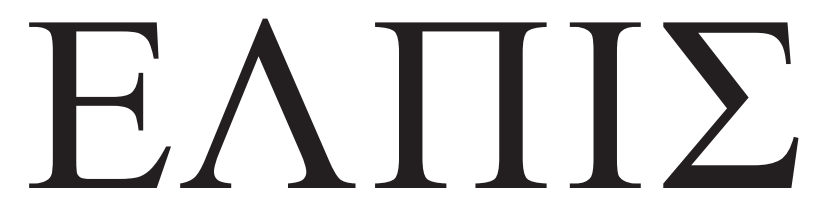

CZASOPISMO TEOLOGICZNE KATEDRY TEOLOGII PRAWOSŁAWNEJ UNIWERSYTETU W BIAŁYMSTOKU

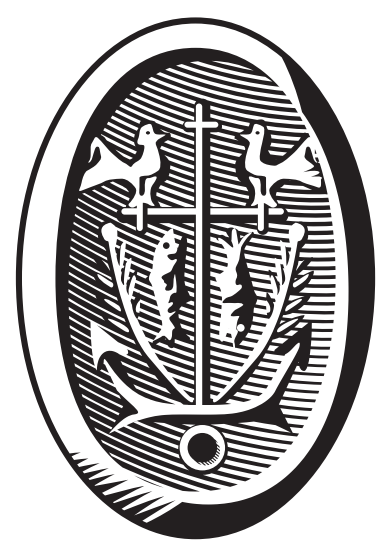

ADRES REDAKCJI

15-097 Białystok, ul. M. Skłodowskiej-Curie 14 tel. 85 745-77-80, e-mail: redakcja@elpis.edu.pl www.elpis.uwb.edu.pl 